DESCARTES AND THE LAST SCHOLASTIC 



\title{
DESGARTES AND THE
}

\section{LAST SGHOLASTICS}

\author{
Roger Ariew
}

Cornell University Press

Ithaca and London 


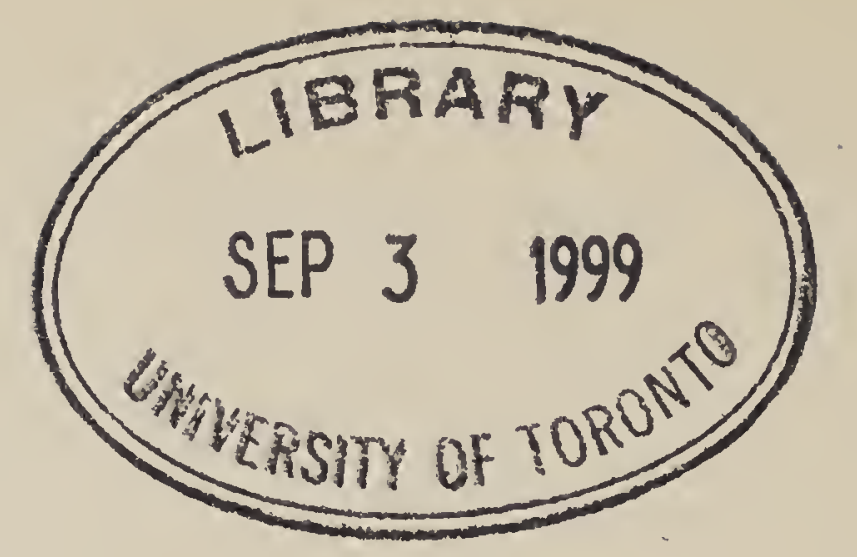

Copyright @ 1999 by Cornell University

All rights reserved. Except for brief quotations in a review, this book, or parts thereof, must not be reproduced in any form without permission in writing from the publisher. For information, address Cornell University Press, Sage House, 512 East State Street, Ithaca, New York $1485^{\circ}$.

First published 1999 by Cornell University Press

Library of Congress Cataloging-in-Publication Data

Ariew, Roger.

Descartes and the last scholastics / Roger Ariew.

p. $\mathrm{cm}$.

Includes bibliographical references and index.

ISBN o-8o 1 4-3603-6 (alk. paper)

1. Descartes, René, 1596-1650. 2. Scholasticism. I. Title. $\mathrm{B}_{1} 875 \cdot \mathrm{A}_{5} \quad 1998$

194-dc2 1

99-11953

\section{Printed in the United States of America}

Cornell University Press strives to use environmentally responsible suppliers and materials to the fullest extent possible in the publishing of its books. Such materials include vegetablebased, low-VOC inks, and acid-free papers that are recycled, totally chlorine-free, or partly composed of nonwood fibers. Books that bear the logo of the FSC (Forest Stewardship Council) use paper taken from forests that have been inspected and certified as meeting the highest standards for environmental and social responsibility. For further information, visit our website at www.cornellpress.cornell.edu.

Cloth printing $\quad 10987654321$ 
For $M G$ and $D G$ 
